УДК 330.3:338.49

JEL classification: B 490; O 018; $R 590$

Тульчинська С. О.

доктор економ. наук, професор ORCID ID: 0000-0002-1409-3848

Національній технічний університет Украӥні «Київський політехнічний інститут імені Ігоря Сікорського»

Тульчинський P. B. канд. економ. наук, доцент ORCID ID: 0000-0003-1605-1403

ПВНЗ «Міжнародний науково-технічний університет імені академіка Юрія Бугая»

\title{
ІНСТИТУЦІОНАЛЬНІ ЗАСАДИ СТАНОВЛЕННЯ НОВОГО РЕГІОНАЛІЗМУ В УКРАЇНІ
}

\section{INSTITUTIONAL BASES OF NEW REGIONALISM IN UKRAINE}

У статті об'єктом дослідження виступає процес становлення нового регіоналізму в Украӥні, предметом - методологічні засади інституціонального підходу та прикладні аспекти інституціонального забезпечення розвитку регіональних суспільних систем. Обтрунтовано використання методології інституціонального підходу щзодо дослідження становлення нового регіоналізму, оскільки методологія інституціонального підходу дає можливість з високим ступенем підпорядкованості та логічності досліджувати процеси та явища становлення нового регіоналізму, визначати інституціональні та управлінські детермінанти становлення нового регіоналізму, що сприятиме окресленню пріоритетних інституціональних напрямів оптимізації прочесу становлення нового регіоналізму.

Проаналізовано інститучійне забезпечення регіонального розвитку в Україні. Встановлено, щчо більшість інституцій становлення нового регіоналізму в Украӥні $\epsilon$ нерозвиненими, що вимагає проведення певних реформ, спрямованих на їх становлення та активізацію діяльності, щуо сприятиме становленню нового регіоналізму в Украӥні. 3'ясовано, що становлення нового регіоналізму зумовлює розроблення та впровадження змін до законодавчо-нормативної бази, яка визначає правові, економічні та організачійні умови функціонування суб'єктів регіонів, здійснення регулювання відносин між ними тощо. Роль інститутів полягає у зменшенні невизначеності при становленні нового регіоналізму, иляхом встановлення стійкої структури взаємодії між суб'єктами регіональних суспільних систем.

Наукова новизна полягає в удосконаленні методологічних засад становлення нового регіоналізму в Украӥні, що, на відміну від наявних, базується на обтрунтуванні використання інституціонального підходу, що обумовлюється неможливістю модернізації регіональних суспільних систем без інституціональних змін соціально-економічної сфери, оскільки під їх впливом формується більш ефективніше використання ресурсів, підвищення конкурентоспроможності, подолання асиметричності регіонального розвитку, формування потенціалу регіонів задля досягнення цілі нового регіоналізму - підвищення якості життя населення регіонів. Практичне значення даного дослідження полягає у тому, що використання методології інституиіонального підходу до становлення нового регіоналізму в Украӥні сприятиме розвитку регіональних суспільних систем.

Ключові слова: новий регіоналізм, інституціональний підхід, методологія, інституції 
The article substantiates the use of the institutional approach methodology to the study of a new regionalism formation. As the institutional approach methodology enables a high degree of subordination and logic to explore the processes and phenomena of a new regionalism formation, to identify the institutional and managerial determinants of a new regionalism formation, which will help to outline the priority institutional directions of optimizing the process of a new regionalism formation.

The institutional support of regional development in Ukraine is analysed. It has been established that most of the institutions of a new regionalism formation in Ukraine are underdeveloped, requiring certain reforms aimed at their formation and activation of activities that will contribute to the new regionalism formation in Ukraine. It was clarified that the new regionalism formation causes the development and introduction of changes in the legislative and regulatory framework that determines the legal, economic and organizational conditions for the functioning of the regions' subjects, the regulation of relations between them, etc. The role of institutions is to reduce uncertainty in a new regionalism formation, by establishing a stable structure of interaction between subjects of regional social systems.

The scientific novelty of the study is to improve the methodological foundations of the emergence of a new regionalism in Ukraine, which, unlike existing ones, is based on the substantiation of the use of the institutional approach, which is conditioned by the impossibility of modernizing regional social systems without institutional changes in the socio-economic sphere, since their influence is shaped by more efficient use resources, increasing competitiveness, overcoming the asymmetry of regional development, building the capacity of regions to reach of new regionalism goals - improving the quality of life of the regions. The practical value of this study is that the use of the methodology of an institutional approach to the formation of a new regionalism in Ukraine will contribute to the development of regional social systems.

Key words: new regionalism, institutional approach, methodology, institutions

Вступ. Сучасний етап розвитку світових економічних відносин визначається процесами глобалізації та інтеграції, що, у свою чергу, вплинуло на створення нової моделі розвитку економічних відносин, а саме становлення нового регіоналізму. Під регіоналізмом, на погляд авторів, необхідно розуміти певну концепцію, що передбачає розширення повноважень та відповідальності регіонів, набуття регіонами, які можуть i не співпадати 3 офіційними адміністративними кордонами, суб'єктності та конкурентоспроможності на світовому ринку [1, с. 154]. Економічний розвиток країни багато в чому залежить від ефективності розвитку їі регіонів, їх конкурентоспроможності на світовому ринку. В Україні становлення нового регіоналізму відзначається розпочатими процесами децентралізації владних повноважень, розробленню стратегічних заходів щодо розвитку регіонів тощо. Але, необхідно зауважити, що становлення нового регіоналізму в Україні вимагає особливої уваги до його теоретико-методологічного підгрунтя.

Серед іноземних дослідників, які досліджують питання нового регіоналізму, необхідно відмітити: І. Бека, Д. Данкерлі,М. Калкуллі, М. Кітінга, М. Легренці, І. Мені, Х.-Ю. Пуле, Е. Томпсона, Л. Фосетта, Шмітта-Егнера, П. Юкарайнена та інші.

Проблемам становлення нового регіоналізму в Україні та обгрунтуванню його теоретико-методологічних засад присвячено праці вітчизняних науковців, а саме: О. Білоруса, І. Бураковського, М. Бутко, Є. Василькова, 3. Варналія, 
А. Гальчинського, Б. Губського, М. Гетьманчука, I. Зварич, Т. Кальченка, Д. Лук'яненка, В. Новицького, Ю. Пахомова, В. Рокочої, О. Чугріни, В. Чужикова, Г. Щедрової, І. Яковюка й інших.

Надаючи належне науковому доробку науковців, необхідно зауважити, що методологічні засади нового регіоналізму залишаються недостатньо розробленими, що ускладнює дослідження становлення нового регіоналізму в Україні та вимагає обгрунтування його концептуально-методологічних засад.

Постановка завдання. Метою дослідження $\epsilon$ подальший розвиток концептуально-методологічних положень становлення нового регіоналізму в Україні у напряму обгрунтування використання методології інституціонального підходу. Для досягнення поставленої мети було вирішено такі завдання: обгрунтовано використання інституціонального підходу щодо становлення нового регіоналізму на основі висунення певних припущень; проаналізовано інституційне забезпечення розвитку регіональних суспільних систем та їх зміни.

Об'єктом дослідження $є$ процес становлення нового регіоналізму в Україні, предметом - методологічні засади інституціонального підходу та прикладні аспекти інституціонального забезпечення розвитку регіональних суспільних систем.

Методологія. Авторами використовувалися загальнонаукові прийоми досліджень та специфічні методи наукового пізнання. Зокрема, застосовувався монографічний метод та метод узагальнень - для обгрунтування використання методології інституціонального підходу; метод аналізу та синтезу - для з'ясування розвиненості інституціонального забезпечення розвитку регіональних суспільних систем. Методологія дослідження базувалась на системному підході, що дало можливість розглядати становлення нового регіоналізму в Україні з системно-функціональної точки зору та обгрунтувати використання методології інституціонального підходу.

Результати дослідження. Методологія інституціонального підходу дає можливість 3 високим ступенем підпорядкованості та логічності досліджувати процеси та явища становлення нового регіоналізму, визначати інституціональні та управлінські детермінанти становлення нового регіоналізму, що сприятиме окресленню пріоритетних інституціональних напрямів щодо оптимізації процесу становлення нового регіоналізму.

Засновником інституціоналізму $\epsilon$ американський економіст лауреат Нобелівської премії Д. Норт (Douglass Cecil North). Науковець у своїй праці «Інститути, інституційні зміни та функціонування економіки» (Institutions, Institutional Change and Economic Performance, 1990) визначив, що «інституції» об'єднують усі види обмежень, що застосовуються для спрямування людської взаємодії в певному напрямі, формою прояву інституцій є інститути [2, с. 49].

Таким чином, за методологією інституціонального підходу основна увага спрямована на функціонування інститутів та їхню роль у становленні нового регіоналізму, до складу яких відносяться: 
- формальні правила - офіційно закріплені у нормативно-законодавчих актах;

- неформальні обмеження - у вигляді договорів та угод різного рівня, історично закріплені традиції, звичаї;

- механізми примусу - забезпечуючи дотримання встановлених правил у вигляді судових та правоохоронних органів тощо.

Використання інституціонального підходу щодо становлення нового регіоналізму спирається на певні припущення:

по-перше, усі чинники впливу на становлення нового регіоналізму та їх результати, діють через інститути та завдяки інститутам, тобто так званий інститутоцентризм;

по-друге, взаємодія та єдність суб'єктів регіонів за становлення нового регіоналізму відбувається завдяки інститутам, що їх визначають;

по-третє, регіони при становленні нового регіоналізму представляються як певна цілісність, що сформувалася під впливом історико-культурного розвитку.

За інституціональним підходом щодо нового регіоналізму вагоме значення надається не тільки суспільним та державним інститутам, а й регіональним різнофункціональним інститутам, що виступають базисом становлення нового регіоналізму та розвитку регіонів, утворюючи певну інституційну сукупність.

Інституційне забезпечення регіонального розвитку відповідно до Конституції та законодавства України здійснюється через: Президента України, Верховну Раду України, Кабінет Міністрів України, Міністерство регіонального розвитку, будівництва та житлово-комунального господарства України, Міністерство економічного розвитку і торгівлі, Міжвідомчу координаційну комісію з питань регіонального розвитку, Раду регіонального розвитку, агенції регіонального розвитку та інші органи виконавчої влади та місцевого самоврядування [3, с. 93].

Головним органом, що забезпечує реалізацію державної політики територіального розвитку з 2007 року є Міністерство регіонального розвитку, будівництва та житлово-комунального господарства України.

Становлення нового регіоналізму, що супроводжується процесом децентралізації, який передбачає передачу певних функцій, повноважень та відповідальності перед суспільством від центральних органів до виконавчих та місцевих органів влади вимагає удосконалення інституційного забезпечення та створення системи інституцій, спроможних забезпечити взаємодію, координацію та зусилля таких інституцій, спрямованих на розвиток регіонів.

Певним кроком у цьому напрямі було створення Кабінетом Міністрів України у 2009 році Ради 3 питань регіонального розвитку та місцевого самоврядування (одними із головних завдань якої $\epsilon$ : проведення аналізу державної регіональної політики, зокрема щодо розвитку місцевого самоврядування; пошук ефективних шляхів іiі вдосконалення; напрацювання спільних планів дій центральних, місцевих органів виконавчої влади та органів місцевого самоврядування 3 метою забезпечення збалансованого розвитку 
регіонів [4]) та у 2015 році Міжвідомчої координаційної комісії з питань регіонального розвитку (одними із головних завдань якої є: забезпечення координації дій органів виконавчої влади із забезпечення формування та реалізації державної регіональної політики, зокрема з обов'язковим залученням органів місцевого самоврядування до формування та реалізації державної регіональної політики, а також до узгодження галузевих прогнозів розвитку регіонів із стратегічними завданнями державної регіональної політики [5]).

Щодо розвитку регіональних суспільних систем, основними законами України є Закони: «Про стимулювання розвитку регіонів» [6], «Про засади державної регіональної політики» [7], «Про державні цільові програми», «Про державне прогнозування та розроблення програм економічного та соціального розвитку України» та інші.

Також Кабінетом Міністрів України затверджено постанову «Про затвердження Державної стратегії регіонального розвитку на період до 2020 року», яка визначає цілі державної регіональної політики та основні завдання центральних та місцевих органів виконавчої влади і органів місцевого самоврядування, спрямовані на їх досягнення, а також передбачає узгодженість державної регіональної політики 3 іншими державними програмами, які спрямовані на територіальний розвиток [8]. Стратегія спрямована на досягнення таких цілей:

по-перше, підвищення рівня конкурентоспроможності регіонів;

по-друге, територіальну соціально-економічну інтеграцію і просторовий розвиток територій;

по-третє, створення інституціональних умов для регіонального розвитку.

Сучасний стан інституційного забезпечення розвитку регіональних суспільних систем характеризується недосконалістю, що проявляється у несистемності та фрагментарності розроблення та впровадження заходів щодо розвитку регіонів, недосконалістю та нерозвиненістю суспільних інституцій підтримки регіонального розвитку та становлення нового регіоналізму.

До інститутів, які впливають на становлення нового регіоналізму, окрім органів державної, регіональної та місцевої влади, можна віднести широке коло інституцій. Практика країн ЄС доводить, що у становленні нового регіоналізму були задіяні такі інституції як [9, с. 140]: національні, регіональні та місцеві агентства розвитку; асоціації муніципалітетів; комунальні фундації; державні інвестиційні корпорації; регіональні інвестиційні та фінансові компанії; державні компанії регіонального розвитку; торговельно-комерційні та промислові палати; приватні консультанти та експерти; гарантійні та благодійні фонди; профспілки; організації, що займаються працевлаштуванням населення; організації, що спеціалізуються на поширенні нових технологій; бізнесінкубатори; технополіси; бізнесові й інноваційні центри; венчурні фонди; заклади вищої освіти та наукові центри; технологічні дослідні лабораторії тощо.

Необхідно зазначити, що більшість перерахованих інституцій в Україні $є$ нерозвиненими, що вимагає проведення певних реформ передбачених 
«Державною стратегією регіонального розвитку на період до 2020 року», спрямованих на їх становлення та активізацію діяльності, що сприятиме становленню нового регіоналізму в Україні.

Висновки. Становлення нового регіоналізму зумовлює розроблення змін до законодавчо-нормативної бази, яка визначає правові, економічні та організаційні умови функціонування суб'єктів регіонів, здійснення регулювання відносин між ними тощо. Роль інститутів полягає у зменшенні невизначеності при становленні нового регіоналізму шляхом встановлення стійкої структури взаємодії між суб'єктами регіональних суспільних систем. Методологія використання інституціонального підходу враховує не тільки зміни правових інститутів, а також зміни глобалізаційних економічних процесів, процеси самоідентифікації регіонів щодо історико-культурних устоїв, оголошених суспільством цілей, завдань тощо.

Наукова новизна полягає в удосконаленні методологічних засад становлення нового регіоналізму в Україні, що, на відміну від наявних, базується на обгрунтуванні використання інституціонального підходу, що обумовлюється неможливістю модернізації регіональних суспільних систем без інституціональних змін соціально-економічної сфери, оскільки під їх впливом формується більш ефективніше використання ресурсів, підвищення конкурентоспроможності, подолання асиметричності регіонального розвитку, формування потенціалу регіонів задля досягнення цілі нового регіоналізму підвищення якості життя населення регіонів.

Практичне значення даного дослідження полягає у тому, що використання методології інституціонального підходу до становлення нового регіоналізму в Україні сприятиме розвитку регіональних суспільних систем за умов урахування не тільки зміни правових інститутів, а також змін глобалізаційних економічних процесів, процесів самоідентифікації регіонів щодо історико-культурних устоїв, оголошених суспільством цілей, завдань тощо.

Подальшого дослідження вимагає з'ясування недоліків інституційного забезпечення щодо становлення нового регіоналізму в Україні та розроблення заходів щодо їх нівелювання.

\section{Література:}

1. Тульчинський Р.В. Регіоналізм та його сутність: різноманіття наукових поглядів. Інноваційна економіка: наук. вир. журнал. 2017. № 11-12 (72). С. 151-155.

2. Норт Д. Інституції, інституційна зміна та функціонування економіки. К.: Основи, 2000. $198 \mathrm{c}$.

3. Тульчинська С.О. Перспективи та домінанти розвитку інтелектуально-інноваційної системи регіонів України: моногр. Херсон: Ви-во «ПП Вишемирський В.С.», 2014. 210 с.

4. Ради з питань регіонального розвитку та місцевого самоврядування: Постанова КМУ за станом від 2 квіт. 2009 р. (Постанова).

5. Міжвідомчої координаційної комісії з питань регіонального розвитку: Постанова КМУ за станом від 16 вер. 2015 р. (Постанова). 
6. Про стимулювання розвитку регіонів: Закон України за станом на 08 верес. 2005 р. / Відомості Верховної Ради України. К.: Парламентське вид-во, 2005. (Закон України).

7. Про засади державної регіональної політики: Закон України за станом на 05 лют. 2015 р. / Відомості Верховної Ради України. К.: Парламентське вид-во, 2015. (Закон України).

8. Про затвердження Державної стратегії регіонального розвитку на період до 2020 року: Постанова КМУ за станом від 6 серп. 2014 р. (Постанова).

9. Тульчинська С.О. Концепція інноваційного розвитку регіонів на основі регіональних переваг. Актуальні проблеми економіки. 2012. №9(135). С. 138-142. 